In terms of socio-economic transformation of society, modernization of secondary and higher pedagogical schools, special importance of a critical rethinking of the whole experience, in-depth analysis of practice training of teachers of technologies, it is necessary to define what experience should be preserved and what should be changed or updated under the influence of new tendencies and processes occurring in society. Updating the content of education is one of the problems of the modern educational industry.

The content of education should embody realization of the social order, that is, the need of society to transfer social experience to the younger generation, which is one of the factors of economic and social progress of society. The younger generation should be focused on ensuring self-determination of the individual, creating conditions for its self-realization; on the development of civil society; on strengthening and improving the rule of law. The content of education in a particular education institution is determined by the educational program, which is developed, adopted and implemented by this education institution independently. Providing the educational process with normative intra-University documents becomes an effective tool for personnel training management and, consequently, continuous improvement of this process in the event that it is systemic and covers all aspects of the learning and education processes.

Today, most education institutions face organizational, technical, financial difficulties in organizing training in the field of computer hardware and software on real hardware with software installed on it, experimenting with which may result in malfunctions or temporary suspension of the equipment. Often, during the practical training, it is not possible to allocate computers to students to study hardware, set up customization and test software for a specific group of students; in most cases, installing and configuring software requires administrator privileges that are not provided to students, based on the need to ensure the security of computers and the educational network; some software installation and setup took a long time to complete.

Key words occupational safety, occupational health and safety management system, civil protection, professional training, informatization, integration, competences.

Кристина Шевчук

Чернівецький національний університет імені Юрія Федоровича ORCID ID 0000-0002-9365-1456

Ганна Бигар

Чернівецький національний університет імені Юрія Федоровича ORCID ID 0000-0001-8373-463X

Аліна Предик

Чернівецький національний університет імені Юрія Федоровича ORCID ID 0000-0001-7356-8690

DOI 10.24139/2312-5993/2020.02/215-224

\title{
ОСОБЛИВОСТІ ПІДГОТОВКИ МАЙБУТНІХ УЧИТЕЛІВ ПОЧАТКОВИХ КЛАСІВ ДО ОРГАНІЗАЦІї КРАЄЗНАВЧОЇ РОБОТИ
}

Стаття присвячена актуальній проблемі сучасної педагогічної парадигми підготовці майбутніх учителів початкових класів до організачії краєзнавчої роботи. Актуальність даної проблеми в науковому обігу зумовлено введенням нових освітніх стандартів, які визначають пріоритетні завдання, що передбачають модернізацію змісту і методів підготовки майбутнього вчителя шляхом повної реалізації його потенційних можливостей. Акцентовано увагу на створенні й функціонуванні в структурі початкової освіти особливої системи знань про культурно-історичні 
особливості рідного краю, що вимагає від випускника педагогічного закладу вищої освіти готовності до їх реалізації у практичній діяльності. Розглянуто особливості підготовки майбутніх учителів початкових класів до організації краєзнавчої роботи через специфріку викладання курсу «Природничо-краєзнавча робота в початковій школі». Зроблено висновок про наявність спеціального методичного інструментарію формування готовності майбутніх учителів початкових класів до організачії краєзнавчої роботи.

Ключові слова: краєзнавча робота, підготовка майбутніх учителів до організації краєзнавчої роботи, особливості фрормування.

Постановка проблеми. Підготовка майбутніх учителів початкових класів до організації краєзнавчої роботи повинна забезпечуватися шляхом: засвоєння студентами необхідних світоглядних знань, що становлять фундамент педагогічної діяльності 3 краєзнавчої роботи; розуміння краєзнавчої роботи як цілісного знання про довкілля, існування сукупності і взаємозв'язку та взаємодії основних компонентів процесу навчання й виховання; органічне поєднання теоретичної та практичної підготовки майбутнього вчителя; формування потреби в знаннях про рідний край; вироблення вмінь самостійного пошуку ефективних форм, методів організації краєзнавчої роботи.

Аналіз актуальних досліджень. Аналіз науково-педагогічних джерел, навчальних планів, програм педагогічних закладів вищої освіти засвідчив, що в системі вищої професійної освіти існує розбіжність у поглядах на питання підготовки майбутніх учителів початкової школи до організації краєзнавчої роботи. Загальні питання, пов'язані з розробкою системи краєзнавчої діяльності загальноосвітньої школи і педагогічного керівництва нею, обґрунтуванням моделі краєзнавчих циклів, вивчалися в роботах Л. Волкова, М. Костриці, М. Крачило, В. Обозного, Б. Чернова. Особливості вивчення рідного краю в початковій школі знайшли своє відображення у працях Т. Байбари, В. Ільченко, Т. Люріної, В. Молодиченка, Т. Олексенко.

Мета статті полягає в розкритті актуальності й особливостей підготовки майбутніх учителів початкових класів до організації краєзнавчої роботи.

Виклад основного матеріалу. Методику підготовки майбутніх учителів початкових класів до організації краєзнавчої роботи хочемо проілюструвати на прикладі викладання на кафедрі педагогіки та методики початкової освіти факультету педагогіки, психології та соціальної роботи Чернівецького національного університету імені Юрія Федьковича дисципліни «Природничо-краєзнавча робота в початковій школі».

Упровадження в навчальний процес курсу «Природничокраєзнавча робота в початковій школі» було побудовано на основі теоретичної підготовки; практичних занять та блоку для самостійного опрацювання.

На кожному лекційному та семінарському занятті одночасно використовується декілька варіантів організаційних прийомів і форм роботи, 
серед яких відповідне місце відводиться таким методичним прийомам, як бесіда, розповідь із застосуванням наочності (Іванчук та Шевчук, 2010).

У навчальному процесі значне місце посідає ілюстрований матеріал, який допомагає ефективніше сприймати навчальний матеріал, формувати конкретні уявлення, точні поняття про рідний край, його походження. Ознайомлення з рідним містом та його минулим відбувається і шляхом розглядання історичних альбомів, краєзнавчих листівок, буклетів, репродукцій, слайдів, відеофільмів про рідне місто (край). Завдяки цьому досягається достатньо високий рівень ефективності освітнього процесу в реалізації основної мети курсу (Олексенко та ін., 2006, с. 40).

Розглянемо детальніше поетапну структуру одного з циклів набуття теоретичних занять:

Етап 1 - підготовчий.

Етап 2 - проведення семінарського заняття.

Етап 3 - аналіз та оцінювання.

Етап 4 - розподіл завдань і визначення складу мікрогрупи для наступного заняття (розподіл підгруп, завдань, форм роботи та ін.).

Далі цикл повторюється із нового змісту (нової теми). Окрім вищезгаданих етапів, можливим $€$ виділення ще одного «проміжного» етапу, обов'язкового під час роботи над кожним із перерахованих вище. Таким етапом слід вважати як моніторинг, який можна використовувати в будь-якій методиці спостережень - авторській, або методиці спостережень (планування), розробленій В. Беспалько, яку застосовуємо для аналізу навчального процесу під час аудиторно-семінарських і практичних занять.

Коротко схарактеризуємо зазначені вище етапи.

Перший етап - підготовка до семінару.

Навчальна група поділяється на 4-5 мікрогруп. Кількісний склад мікрогрупи становить 3-4 осіби. Кожній мікрогрупі дається індивідуальне завдання відповідно до таксономії навчальних завдань. Наприклад:

Мікрогрупа 1. Підготувати тестове завдання: 15 завдань із 3 варіантами відповідей на кожне завдання.

Мікрогрупа 2. Скласти кросворд за термінами семінарського заняття.

Мікрогрупа 3. Розробити схему/діаграму до кожного питання теми семінарського заняття (з вказівкою термінів, понять та інше).

Мікрогрупа 4. Підготувати повідомлення на основі письмового плану. План здається викладачу до початку відповіді.

Мікрогрупа 5. Підготувати анотації з проблем семінарського заняття 3 періодичної преси, а також наукових публікацій, у яких розглядаються проблеми організації шкільного краєзнавства, діяльності закладів освіти краєзнавчої спрямованості. Для складання анотацій дається кількість статей, відповідно до кількості членів мікрогрупи. Обсяг анотації - до 2 сторінок рукописного тексту. 
Одержавши завдання, кожна мікрогрупа самостійно розподіляє між своїми членами обсяг і рівень складності діяльності, час підготовки та ін. На підготовку дається 1-2 тижні, які відповідають загальноприйнятому графіку навчального процесу в університеті.

Другий етап - проведення семінарського заняття.

Хід заняття (варіант):

1. Тестове завдання з попереднього заняття (10-15 хв.).

2. Виступи майбутніх учителів початкових класів четвертої мікрогрупи 3 повідомленням із проблем семінарського заняття. Під час повідомлення кожна інша мікрогрупа готує 3-5 питань за кожним обговорюваним матеріалом (45-50 хв.), завдяки чому досягається активне слухання матеріалу.

3. Бліц. Мікрогрупи в швидкому темпі задають питання один одному 3 теми повідомлення. Доповідач виступає в ролі експерта. Бліц проводиться після кожного повідомлення (20-25 хв.).

4. Виконання усних та письмових завдань, підготовлених мікрогрупами в період підготовки до семінарського заняття вдома (15 хв.).

5. Аналіз і оцінювання діяльності майбутніх учителів початкових класів під час заняття (5 хв.).

6. Розподіл і обговорення завдань по мікрогрупах для підготовки до чергового семінарського заняття (10 хв.).

Третій етап - аналіз та оцінювання.

На занятті проводиться оцінювання діяльності майбутніх учителів початкових класів та викладача за допомогою:

а) самозвітів (самооцінки) майбутніх учителів початкових класів та викладача;

б) оцінювання результатів тестових завдань;

в) обліку рівня активності майбутнього вчителя під час заняття (кількість питань, відповідей, видів виконаних завдань);

г) взаємовідвідування та ін.

За підсумками кожного заняття викладач має можливість об'єктивно оцінити діяльність усіх, без виключення, майбутніх учителів початкових класів, що без сумніву веде до зниження рівня суб'єктивізму в оцінюванні якості знань, умінь і навичок (Предик, 2017).

Підсумкова оцінка (за повний курс) діяльності кожного окремого майбутнього вчителя виводиться на підставі середньої суми балів, отриманих за кожне семінарське заняття. При цьому обов'язково враховується рівень складності виконаних завдань (згідно з таксономією форм навчальних завдань).

Четвертий етап - розподіл завдань і визначення складу мікрогруп для наступного заняття.

Розподіл завдань у мікрогрупах на наступне семінарське заняття проводиться з урахуванням раніше проведених семінарів із тим, щоб 
забезпечити можливість кожному майбутньому вчителю початкових класів отримати навички роботи зі всією різноманітністю форм навчальнопедагогічної діяльності. Однією з бажаних умов даної технології організації теоретичних занять $€$ розподіл майбутніх учителів початкових класів на мікрогрупи й обов'язкова змінюваність форм та видів завдань для самостійної позакласної роботи.

Зміст сучасної підготовки майбутніх учителів є своєрідною моделлю професіоналізму, яка відображає вимоги суспільства, науково обґрунтований склад професійних знань, умінь і навичок, упровадження розвивальної інтегрованої технології (Шевчук, 2007, с. 206).

Основне завдання закладів вищої освіти - надати якісну підготовку майбутньої педагогічної навчально-виховної роботи. Така підготовка включає: озброєння майбутніх учителів необхідними базовими знаннями 3 певної кваліфікації, формування необхідних професійних умінь і навичок та особистісних якостей тощо (Люріна, 2004, с. 286).

Сьогодні у зв'язку зі зростанням вимог до освітньої та професійної підготовки молодого вчителя виникла необхідність здійснювати перехід до індивідуального підходу в навчанні, розвитку творчих здібностей майбутніх учителів, спираючись на їх самостійну роботу, активні форми та методи навчання.

Якісне формування творчого, ініціативного, самокритичного педагога може бути здійснено лише тоді, коли майбутній учитель уже в роки навчання в педагогічному ЗВО буде поставлений в умови, наближені до його практичної діяльності за допомогою активних методів навчання, що готують його до співпраці з учнями.

Для підвищення ефективності підготовки майбутніх учителів початкових класів до організації краєзнавчої роботи необхідний триваліший процес, який включає весь потенціал навчального плану роботи факультетів, позанавчальної роботи куратора академічної групи та діяльності студентських неформальних об'єднань, науково-дослідницької діяльності майбутніх учителів та ін. (Обозний, 2001, с. 138).

Розглянемо організаційні форми системи краєзнавчої роботи майбутніх учителів початкової школи в цілісній педагогічній системі закладів вищої професійної (педагогічної) освіти.

Аналіз джерельної бази дозволив виділити найбільш загальні організаційні форми навчального процесу під час підготовки майбутніх учителів початкових класів до організації краєзнавчої роботи.

Організаційна форма 1. Формальна підготовка (за В. Беспалько, М. Кострицею), що здійснюється в процесі навчальної роботи в закладах вищої освіти відображена в навчальному плані і програмах, робочих програмах, змісті педагогічних практик, спецкурсах, тематиці курсових та дипломних робіт, програмах діяльності проблемних наукових груп, наукових гуртків, науково-методичних лабораторій. 
Організаційна форма 2. Неформальна підготовка, або «м'яка» форма за Л. Бергом, що здійснюється в процесі позаурочної діяльності в закладах вищої освіти (участь у роботі фольклорних об'єднань, гуртків, проведення походів, участь у студентських краєзнавчих вікторинах, бесідах).

Організаційна форма 3. Самостійна домашня робота і самоосвіта, які, на нашу думку, можуть бути віднесені до проміжної форми, що поєднує в собі як «жорсткість» формальних організаційних форм при чітко визначених і сформульованих домашніх завданнях студентам, так і «м'якість» неформальних, залежних від особистих інтересів та потреб студентів.

Передбачено, що формальна підготовка - 1, повинна давати майбутнім учителям початкових класів змогу оволодіння базовим компонентом знань, умінь і навичок із організації краєзнавчої роботи, необхідних для використання ії як допоміжного засобу виховання.

Що стосується неформальної підготовки - 2, а також формальної підготовки - 3, то вони більшою мірою спрямовані на процеси самопізнання, саморозвитку й самоактуалізації особистості майбутніх учителів початкових класів. Вони розглядаються як додаткові, спрямовані на перспективу розвитку особистості майбутніх учителів і можуть надалі послужити основою для підвищення кваліфікації вчителів на 3-5 рівнях національної системи. При цьому на будь-якому з розглянутих вище рівнів майбутніми вчителями початкових класів можуть ставитися окрім соціальних, педагогічних цілей, також і особисті:

1. Майбутній учитель початкових класів не ставить перед собою мету отримати високі спортивні досягнення в краєзнавчій діяльності, а прагне тільки розширити особистий кругозір, підвищити науково-методичний потенціал тощо.

2. Майбутній учитель початкових класів, беручи участь у «походахвипробуваннях», змаганнях, конкурсах та ін., зосереджується, у першу чергу, на меті вдосконалення особистої краєзнавчої підготовки, самореалізації, самовдосконалення особистісної діяльності. Розширення кругозору, розвиток рекреаційної культури, взаємостосунки між одногрупниками є другорядними цілями. Не підлягає сумніву, що таке розмежування цілей не відіграє ролі в участі майбутніх учителів початкових класів у неформальних формах організації краєзнавчої роботи, і свідчить про достатньо високий прояв інтересу до даного виду діяльності (високий рівень мотивації).

Цікавою є система краєзнавчих циклів, розроблена В. Обозним (Обозний, 2011, с. 110). Вона складається з 2-х логічно завершених циклів (концентрів), що дозволяють сформувати в майбутніх учителів початкових класів середній і високий рівні володіння методикою здійснення краєзнавчої роботи школярів залежно від ступеня вмотивованості, інтересу, фізичних можливостей і схильностей їх більшості. 
Найбільш значущим у системи педагогічного закладу вищої освіти 3 організації краєзнавчої роботи, на наш погляд, $€$ використання таких організаційних форм, що дають можливість майбутнім учителям початкових класів подолати зміну свого соціального статусу й полегшити перехід майбутнього вчителя початкових класів до виконання ролі педагога-організатора, у взаємозв'язку урочної та позаурочної діяльності. До таких форм відносимо:

а) авторську розробку й реалізацію в період проходження педагогічної практики краєзнавчих сценаріїв, програм проведення краєзнавчих колективних творчих заходів;

б) розробку та проведення майбутніми вчителями початкових класів традиційного «походу-випробування»;

в) роботу майбутніх учителів початкових класів - керівників краєзнавчих гуртків при Будинках школярів;

г) науково-дослідницьку роботу (участь у проблемній групі, написання курсових та дипломних робіт, виступи на науково-практичних конференціях).

Саме ці форми підготовки майбутніх учителів початкових класів до організації краєзнавчої роботи дозволяють сумістити дві ролі - одночасно роль майбутнього вчителя початкових класів і роль учителя-дослідника. Таким чином, ми можемо спостерігати такий процес становлення особистості вчителя початкових класів (Пангелов та Чернов, 2005, с. 618):

1) усвідомлення власного «Я» як учителя («Я» концепція);

2) усвідомлення оточуючої педагогічної діяльності («Д» концепція);

3) усвідомлення особистості молодшого школяра, її сприйняття навколишнього світу і тієї дії, яку на неї спричиняє вчитель своїми діями.

Отже, кожна з тактичних форм організації навчального процесу має свою структуру, алгоритм підготовки, проведення й підбиття підсумків, відповідне навчально-методичне та матеріальне забезпечення.

Висновки. Продуктивне формування готовності майбутніх учителів початкових класів до організації краєзнавчої роботи вимагає: визначення змісту, форм і методів означеної підготовки; збагачення курсів гуманітарних, соціально-орієнтованих і фундаментально-професійних дисциплін, педагогічної практики; доповнення тем, розробки завдань та тестів для практичних занять; накопичення навчально-методичного матеріалу для проведення краєзнавчої роботи з учнями, виконання практичних завдань, тренінгів та інших форм роботи, які забезпечили 6 їх відповідність практиці краєзнавчої діяльності в початковій школі.

\section{ЛІТЕРАТУРА}

Байраківський, А. І., Бажан, О. Г. та ін. (2003). Краєзнавство в Україні: сучасний стан і перспективи. Наук. збірник НАН України. К.: Вид. центр «Академія» (Bairaksvskys, A. I., Bazhan, O. G. et al. (2003). Local History in Ukraine: Current State and Prospects. Scient. Collection of NAS of Ukraine. Kyiv). 
Іванчук, М. Г., Шевчук, К. Д. (2010). Виховний потенціал рідного краю (виховання у молодших школярів ціннісного ставлення до природи рідного краю). Чернівці (Ivanchuk, M. G., Shevchuk, K. D. (2010). The upbringing potential of the native land (upbringing of a valuable attitude towards the nature of their native land among the younger students). Chernivtsi).

Люріна, Т. І. (2004). Деякі аспекти підготовки вчителя початкових класів до формування в учнів ціннісних орієнтирів. Матеріали Міжнародної науково-методичної конференції 1-2 квітня 2004 р., сc. 285-287 (Liurina, T. I. (2004). Some aspects of training primary school teachers for forming students' value orientations. Proceedings of the International Scientific and Methodological Conference April 1-2, 2004, pp. 285-287).

Москаленко, В. В. (2005). Соціальна психологія. К.: Центр навч. літератури (M oskalenko, V. V. (2005). Social Psychology. K.: Center for Teaching literature).

Обозний, В. В. (2001). Краєзнавча підготовка вчителя: теоретичні і організаційнопрактичні аспекти. К.: Вид-во НПУ ім. М. П. Драгоманова. (Oboznyi, V. V. (2001). Local lore teacher training: theoretical and organizational-practical aspects. K.: Publishing house of NPU named after M .P. Drahomanov).

Олексенко, Т. Д., Люріна, Т. І., Молодиченко, В. В. (2006). Вивчення рідного краю в початковій школі. Рідна школа, 1, 40-42 (Oleksenko, T. D., Liurina, T. I., Molodychenko, V. V. (2006). Study of the Native Land at Primary School. Native School, 1, 40-42).

Пангелов, Б. П., Чернов, Б. О. (2005). Програмно-нормативні основи підготовки майбутніх вчителів до туристсько-краєзнавчої роботи в загальноосвітній школі. Культура і освіта фрахівців туристської сфери: сучасні тенденції та прогнози: Матеріал Міжнародної науково-практичної конфреренції. Київ, сс. 617-621 (Pangelov, B. P., Chernov, B. O. (2005). Program-normative bases of training of future teachers for tourist-local lore work at secondary school. Culture and Education of Tourism Specialists: Current Trends and Forecasts: Proceedings of the International Scientific and Practical Conference. Kyiv, pp. 617-621).

Предик, А. А. (2017). Ділова гра як засіб підготовки майбутніх вчителів початкових класів до професійної діяльності. Scientific Journal Virtus. M arch, issue 12, 157-159 (Predyk, A. A. (2017). Business play as a means of training future primary school teachers for professional activity. Scientific Journal Virtus. March, issue 12, 157-159).

Шевчук, К. (2007). Підготовка майбутніх вчителів до формування у молодших школярів ціннісного ставлення до рідного краю. Науковий вісник Чернівецького університету. Педагогіка та психологія, Вип. 362, 206-212 (Shevchuk, K. (2007). Training of future teachers for the formation of a valuable attitude towards their native land among the junior schoolchildren. Scientific Bulletin of Chernivtsi University. Pedagogy and Psychology, 362, 206-212).

\section{PEЗЮME}

Шевчук Кристина, Бигар Анна, Предик Алина. Особенности подготовки будущих учителей начальных классов к организации краеведческой работы.

Статья посвящена актуальной проблеме современной педагогической парадигмы - подготовке будущих учителей начальных классов к организации краеведческой работы. Актуальность данной проблемы обусловлена введением новых образовательных стандартов, которые определяют приоритетные задачи, предусматривая модернизацию содержания и методов подготовки будущих учителей путем полной реализации их потенциальных возможностей. Акцентировано внимание на создании и функционировании в структуре начального 
образования особой системы знаний о культурно-исторических особенностях родного края, что в свою очередь требует от выпускника высшего педагогчческого учебного заведения готовности к их реализации в практической деятельности. Рассмотрены особенности подготовки будущих учителей начальных классов $к$ организации краеведческой работы в силу специфики преподавания курса "Краеведческая работа в начальной школе». Сделан вывод о наличии специального методического инструментария формирования готовности будущих учителей начальных классов к организации краеведческой работы.

Ключевые слова: краеведческая работа, подготовка будущих учителей к организации краеведческой работы, особенности формирования.

\section{SUMMARY}

Shevchuk Kystyna, Bygar Hanna, Predyk Alina. The peculiarities of future primary school teachers training to the organization of local lore work.

The article is devoted to the actual problem of the modern pedagogical paradigm training of future primary school teachers for the organization of local lore work. The urgency of this problem in the scientific circles is conditioned by the introduction of new educational standards, which determine the priorities, and it involves modernization of the content and methods of training a future teacher through full realization of his potential. The emphasis is on the creation and functioning of a special system of knowledge in the structure of primary education about the cultural and historical peculiarities of the native land, which requires a graduate of a higher education institution to be ready to put them into practice.

The results of the theoretical analysis of foreign and domestic experience have revealed that transition to systematic local lore work in the system of primary education is due to specific historical events, patterns of socio-political, cultural development of society and the dynamics of the education system in its focus on fostering a sense of patriotism by using the potential of local history. The content, forms and methods of training future primary school teachers to the organization of local lore work which would ensure their effectiveness in practice at school are theoretically substantiated and determined.

The peculiarities of training of future primary school teachers for the defined activity are analyzed. This activity is provided by: mastering the necessary philosophical knowledge, which is the foundation of educational activities of local lore work; understanding of local lore work as holistic knowledge of the environment, the existence of the totality and interconnection, interaction of the main components of the learning and upbringing processes - a goal, objectives, principles, a subject, an object, content, forms and methods; an organic combination of theoretical and practical training of the student; formation of the need for knowledge about the native land (skills to set the purpose and tasks of the organization of local lore work correctly, to control the process and analyze its effectiveness); developing the skills of independent search for effective forms, methods of the organization of local lore work.

The authors have analyzed organizational forms of the system of local lore work of future primary school teachers in the holistic pedagogical system of institutions of higher professional (pedagogical) education. It has been proved that each of the tactical forms of the organization of the educational process has its own structure, algorithm of training, conducting and summing up, appropriate educational and methodological and material support.

Thus, the productive formation of readiness of future primary school teachers to the organization of local lore work requires, besides defining the content, forms and methods of specific training; enrichment of the courses of humanities, socially oriented and fundamentally professional disciplines, pedagogical practice; supplementing topics, developing tasks and tests for practical classes; accumulation of educational and methodological material for carrying out local lore work with students, performing practical 
tasks, trainings and other forms of work, which would ensure their relevance to the practice of local lore activity at the primary school.

Key words primary school, primary school teachers, local lore work, the system of primary education, content, forms, methods, skills.

Удк 378.147

Світлана Шестакова

Сумський національний аграрний університет

ORCID ID 0000-0003-4640-0379

DOI 10.24139/2312-5993/2020.02/224-233

\section{ВИКОРИСТАННЯ ІНТЕРАКТИВНИХ МЕТОДІВ НАВЧАННЯ ДЛЯ ФОРМУВАННЯ SOFTSWUSУ СТУДЕНТІВ ЮРИДИЧНОГО ПРОФІЛЮ}

у статті досліджуються інтерактивні методи формування soft skills $y$ студентів юридичного факультету, визначаються особливості «м'яких» навичок, необхідних для ефрективного виконання професійних завдань сучасним юристом (зокрема, комунікації, дипломатії, створення чи підтримання сприятливого мікроклімату в колективі, уміння працювати в команді, виступати публічно, презентувати себе та свої ідеї, креативно вирішувати професійні завдання тощо). Акцентується увага на суперечності закріплених в освітніх стандартах вимог і наявної тенденції до зменшення кількості гуманітарних дисциплін. Наводяться апробовані типи занять, що є найбільш ефективними для формування «м'яких» навичок.

Ключові слова: soft skills, «м'які» навички, комунікативна компетентність, загальні компетенції, професійні навички, інтерактивні методи навчання.

Постановка проблеми. Становлення української державності, зміни правосвідомості громадян, реформування судової системи, радикальні зміни у змісті форм і методів діяльності юристів висувають високі вимоги до їх професійної підготовки, ділових якостей, загальної культури, а також мовної майстерності.

Престижність юридичної професії, ії затребуваність у суспільстві зумовили збільшення контингенту юридичних факультетів і відкриття даної спеціальності в непрофільних вишах. Звичайно, це загострило завдання якісної професійної підготовки й вимагає пошуку та застосування ефективних засобів і методів формування професійно значущих характеристик особистості майбутніх фахівців.

Сьогодні у випускників юридичних факультетів виникає потреба не тільки у знаннях і вміннях вирішувати професійні завдання, але й у здібностях до взаємодії з колегами, з реальними й потенційними споживачами юридичних послуг, до швидкого переходу від одного виду діяльності до іншого і поєднання різних професійних функцій.

Проте, на сучасному етапі ми можемо говорити про невідповідність наявної системи підготовки фахівців вимогам ринку праці, зокрема і в юридичній галузі. Випускникам закладів вищої освіти, які мають недостатній рівень сформованості так званих «м'яких» компетенцій, доводиться конкурувати з більш досвідченими претендентами на вакантну 